7 (2016)

DOI: $10.18276 /$ rk.2016.7-16

Ursula Phillips

UCL School of Slavonic and East European Studies (SSEES)

\title{
With Open Eyes: The Young Narcyza Żmichowska's Reception of Western Cultural Influences
}

Narcyza Żmichowska (1819-1876) is not a name instantly recognizable outside Poland. In the English-speaking world, however, she is not unknown thanks to research on women's history, where she is usually discussed in connection with the group of women with whom she was associated in the 1840s known as the Enthusiasts (Fraisse and Perrot, 1993: 485). It is thanks to the appearance of Grażyna Borkowska's book in English (2001) that her achievements as a literary author have become better known among Slavists and women's literature researchers outside Poland. An English translation of Żmichowska's best known novel Poganka (The Heathen) appeared in 2012 with a substantial introduction placing the work in both its Polish and European contemporary contexts (Żmichowska, 2012). Recently, this novel has featured alongside works by Charlotte Brontë, Daphne du Maurier and others, in a $\mathrm{PhD}$ dissertation inspired by psychoanalytic theories of femininity and mirroring, thereby proving her potential for comparative analysis (Naszkowska, 2012). The aim of the current article is to discuss this non-Polish context, and how foreign inspirations made their way into Żmichowska's work and thinking.

Like many other Polish cultural figures, Żmichowska maintained a close connection with France, although she never became an émigrée. Her literary activity is a testament nonetheless to how, despite spending more or less her whole life in the partitioned Polish lands, mostly in the Russian partition but also in the 1840 s in the Poznań region of the Prussian, she was able to keep abreast of philosophical, political and literary developments in France and Germany and, in the latter part of her life, in Britain, North America, Italy and Scandinavia. She was phenomenally well-read and self-taught, not only in foreign literature but also in many scientific disciplines, albeit somewhat randomly, depending on the authors to whom she had access (Phillips, 2015). The current article will address the formative phase of her 
encounters with the foreign, covering her school years, stay in France in the late 1830s, and early literary career culminating in The Heathen (1846; 1861, 2nd ed. with frame added), initially published when she was twenty-seven.

An invaluable source for tracing the course of her self-education, reading, opinions and career is the vast correspondence that she maintained throughout her life, now available in five volumes (Żmichowska, 1957, 1960, 1967, 2007, 2009). This correspondence, together with an early diary, provides the underpinning for the following considerations, which will focus primarily on non-Polish literary inspirations and on Żmichowska's religious life, which was most unusual given the traditional Catholic environment in which she was raised.

First of all, however, it is important to understand the contexts in which she functioned, in order to appreciate how she was unusually receptive. It is essential to remember, for example, that during Żmichowska's lifetime, there was no autonomous entity called Poland on the political map of Europe. The former Polish territories were divided between the Russian, Prussian and Austrian empires and hence between three different governing authorities, all autocratic and all having vigorous acculturation policies, especially the former two. The psychological shock that loss of self-determination dealt to all levels of Polish society should not be underestimated. It would be well into the $19^{\text {th }}$ century before it became clear that the language and culture could survive without a political national state; in 1795 this was not so obvious. Writers were therefore burdened with the patriotic duty of promoting the Polish language in order to preserve its historical significance and give succour to present-day compatriots. With the tsarist clampdown that began in the early 1820s, defeat of the 1830 November Insurrection in the Russian partition, flight abroad of supporters (including Żmichowska's brother Erazm), a generation of Polish writers was forced to write either in emigration, mainly in France, or to exploit allusive parabolic language so as to circumnavigate the censorship.

And it is therefore additionally important, when we emphasize Żmichowska's openness to "foreignness," to know how she has been understood by Polish scholars in the past. Before Borkowska's ground-breaking study, which reassessed Żmichowska's literary output as one of considerable creative complexity, as well as tried to pinpoint precisely what her "feminism" depended on, Polish evaluations of her tended to fall into two camps, both of which stretch back to her lifetime, and both of which privilege political and/or personal claims over the artistic, thus looking to her literary texts for evidence of a certain "position": either she was a typical Romantic conspirator, a patriot devoted to national liberation, writing in a coded or Aesopian language, or she was a dangerous "Saint-Simonist" with 
democratic leanings, an advocate of women's emancipation, a free-thinker shocking to traditional Catholicism (Stępień, 1968; Woźniakiewicz-Dziadosz, 1978). In communist People's Poland (1945-1989), the Romantic, conspiratorial, Aesopian Żmichowska predominated, while the playwright Tadeusz Różewicz (1977) perpetuated the lesbian inferences - an interpretation restated by some post-1989 critics such as Sławomira Walczewska (1999).

Żmichowska's contact with the French language began early, as was typical for girls of her social class, but few took their knowledge to such lengths. Born in Warsaw in 1819 as the ninth child of a family of impoverished petty landowners, she received a good formal education for a girl from her background. From 1826 she was a pupil at Zuzanna Wilczyńska's boarding school in Warsaw and in 1832 entered the Institute for Governesses, graduating from there in 1833. After this, she lived for three years on the estate of her uncle and aunt Józef and Maria Kiedryński at Mężenin, near Łomża, during which she read profusely, mostly French literature and history, anything she could lay her hands on. During these early years of formal and informal education, Żmichowska kept a sporadic diary, from which it is possible to learn what titles she read (Żmichowska, Baranowska, 2006: 18-93).

In the first part, entitled At Boarding School ( $N a$ pensji), she records having read "romances in the spirit of Walter Scott" as well as translations of Scott himself, including Ivanhoe, although she quotes the translated title Ryszard Lwie serce w Palestynie. Roman historyczny (Richard the Lion Heart in Palestine: An Historical Romance). She records another historical romance simply as Renegat, most likely Le Rénégat (1822) by Charles Victor Prévot, which appeared in a Polish translation in Wilno in 1825 (Żmichowska, Baranowska, 2006: 30, 390). In addition, there is a sensational-sentimental French romance in Polish translation by the "pseudonymous Hippolyte" (Warsaw, 1827), which is in fact Melina de Cressange, ou les Souterrains de château d'Orfeuil by M. Hyppolyte (Paris, 1820, 3 vols), a book she was chided for reading by her headmistress! (Żmichowska, Baranowska, 2006: 22-23)

From the diary covering the three years at Mężenin, we can see how her reading became rapidly more sophisticated. In addition to major works of Polish Romanticism - to which she had access despite censorship restrictions in the Russian partition - such as Part IV of Adam Mickiewicz's Forefathers' Eve, though not the patriotic Part III, and Konrad Wallenrod, she read Goethe's The Sufferings of Young Werther, it is not clear whether in the Polish translation (1822) by poet and critic Kazimierz Brodziński, or in the German original. She enjoyed Friedrich Schiller and George Sand, but does not record specific titles (Żmichowska, Baranowska, 2006: 44). She similarly admired Michel Masson's Le Cour d'une jeune fille (1834), 
although this was one to which her aunt objected, but did not disallow: "Sometimes I had to read a sentence aloud to myself, in order to better convince myself that I am seeing it on the printed page, and that it is not my own thought." However, she is also critical: "But some of the events seemed to me excessive, and I would have left out certain descriptions quite unsuited to the title of the book" (Żmichowska, Baranowska, 2006: 49).

In 1835 , in the next section of the diary, which consists of a series of letters ostensibly written to a friend from the Institute of Governesses Ludwika Michałowska but never intended to be sent (as Romankówana explains, this was merely a new form of expression - which, we might add, was later to become her main one), Żmichowska lists further works by French authors. The first is Lamartine, quoting in French a couple of lines from the poem $L a$ foi, from the collection Méditations poétiques (1820): "I am quoting him because I am totally immersed in his verses and learning them by heart" (Żmichowska, Baranowska, 2006: 57). In this same "letter," she makes a plea for international tolerance inspired by her sister Hortensja's marriage to a German: "I am not going to justify his country to you nor to myself, because I like Germans." She also mentions Riquet à la Houppe (Żmichowska, Baranowska, 2006: 55), one of Charles Perrault's Histoires ou contes du temps passé (1697). It is clear that she was now reading these things in French and not in Polish translation. The most important work of fiction, however, read at this time is Germaine de Staël's novel Corinne, ou l'Italie (1807), because this work was later to have a decisive influence on her use of the term "enthusiasm" in the 1840s (Żmichowska, Baranowska, 2006: 66).

Of historical works, she records: Claude-Carloman de Rulhière (1735-1791), Histoire de l'anarchie de Pologne et du démembrement de cette république, suivie des anecdotes sure la revolution de Russie (1807); Louis Philippe Ségur (1753-1830), Histoire de France (1824-1834); Pierre-François Tissot (1768-1854), Trophées des armées françaises depuis 1792 jusquien 1815 (1819). Her brief comments suggest that her reception was positive, but she does not elaborate more fully (Żmichowska, Baranowska, 2006: 67). These are serious scholarly works and quite a challenge for a sixteen-year-old... However, her choice of reading was determined - and limited - by what was available in her uncle Kiedryński's library.

It seems that she had unrestricted access to this library, although her choice of books was without system or guidance as to what was important or valuable, and that no serious attempt was made to censor her (though, as we saw above, headmistress Wilczyńska and aunt Kiedrzyńska occasionally expressed disapproval). This is noteworthy in the wider contemporary context of controlling women's reading, 
as well as of widespread fears about "feverish" reading habits in themselves being "infectious" and in some way morally threatening. These transnational concerns had their specifically Polish equivalent. Certain subjects were deemed inappropriate and even corrupting in an ideologically framed environment, where the duty of women was to raise children, be good Polish patriots and Catholics, as in the writings of Klementyna Tańska-Hofmannowa (1798-1845). Such attitudes were to continue into Żmichowska's own generation, with the publication of the conservative, anti-Hegelian philosopher Eleanora Ziemięcka's book on women's education (1843). Both Ziemięcka in her chapter on women writers, as well as Tańska-Hofmannowa in various novels written for girls, warned against the moral dangers of reading French fiction (Phillips, 1999; Phillips 2008). Allegedly, these works which included Rousseau's La Nouvelle Hêloïse, Germaine de Staël's Delphine, De Krudener's Valérie, other novels by De Staël or by George Sand, not to mention less sophisticated popular romances, were believed to encourage unhealthy feelings towards the opposite sex and delusions of happiness invested in romantic alliances, all of which were deemed contrary to standard religious values and women's duty to marry according to conventional criteria. In the Polish context, this conservative moral reaction acquired the added attribute of patriotism, and hence the French texts were tainted, according to these critics, by the polluting potential of the "foreign."

Meanwhile, Żmichowska during 1838-1839 made her first visit to France, where her reading was similarly uncensored, either by the constraints of political censorship and hence of practical access, or by social convention. Here she found the thing she needed most, a guide and mentor, in the person of her own brother Erazm, resident in France, a member of the Polish Democratic Society, and dedicated not only to the restoration of Polish independence but to radical social reforms. Żmichowska travelled to Paris as governess to the children of Konstanty Zamoyski, an aristocrat and official loyal to the tsarist regime and a social conservative. In this environment, where the family was suspicious of her brother's connections and refused to entertain Polish political exiles such as Mickiewicz, Żmichowska lasted barely a few months before moving to live with Erazm in Rheims. It is not entirely clear from her correspondence, but it appears she later returned to Paris for a further spell. Encouraged by Erazm, she was one of the first female readers at the Bibliothèque Nationale, where she attended regularly without a chaperone (Źmichowska, 1957: 108). It also seems that this was the only period in her life when she could simply buy a book she desired in a bookshop (Żmichowska, 1960: 7). 
She was especially interested in contemporary philosophy and theological discussions, and literature, wanting to get to know the most important French, German, English and Italian authors. As she followed Erazm's suggestions, sometimes enthusiastically impressed, at other times polemicizing with the authors in letters to him, she quickly became independent and able to make her own choices. What is most important, however, is the impact her reading in Paris - as well as in the early 1840s, after her return to the Polish lands, when she was associated with the progressive Warsaw journal Przeglad Naukowy (The Scientific Review, 1842-1848) and its radical young editors Edward Dembowski and Henryk Skimborowicz - had on her own thinking. Three things stand out: first, the group of women associated with the Review, whom she called The Enthusiasts, a proto-feminist formation, according to recent assessments; second, the impact of this foreign reading on her most well-known literary text, the novel The Heathen, serialized in the Review in 1846; and third, the direction taken by her religious views.

We know from her contemporary correspondence that while still in Paris, she read Lamennais, Leibniz, Friedrich Schlegel, Fichte, Schelling, Kant (the Germans in French translation), as well as French literary texts including Chateaubriand's René, Frédéric Soulié and Eugène Sue, George Sand's Lélia. Encouraged by Erazm, she also read the entire New Testament and the "lofty" commentaries of Lamennais. Despite being only twenty years old, she says, she finds his utopian optimism, what she terms "dreams of the future" hard to believe, a reaction perhaps determined by the pessimistic outlook at home. She nonetheless mentions two other works by Lamennais, which she read already in 1838: Paroles d'un croyant (1834) and Le Livre du people (1837), and which she admits were "difficult," yet she learns certain passages by heart in order to smuggle them over the border into Poland, where the books themselves could have been impounded (Żmichowska, 1957: 87-88). Meanwhile, in a comment on Friedrich Schlegel, whom she read in French translation, she takes issue with his necessary connection between Christianity and the conservative political system of hereditary monarchy; on the contrary, she links Christian faith with the "democratic" views of her brother, anticipating her interest also in the utopian writings of Pierre Leroux (Żmichowska, 1957: 109).

She also mentions in a (real) letter to Feliks Michałowski, brother of the above-mentioned Ludwika, her reading of George Sand's Lélia (1833, $1^{\text {st }}$ ed.). She is in two minds about the work: she is sympathetic to the sufferings of the "beautiful spiritualist," none of which are "alien" to her, yet frustrated by the privileged Lélia, whose wealth renders her lazy and bored - maybe if she had to earn a living like a poor mother, she would have been more energetic and satisfied with life? 
(Źmichowska, 1960: 455-456)). This novel was nevertheless one of the many texts that possibly influenced The Heathen. Let us speculate too on the origins of Żmichowska's pseudonym Gabriella, or Gabryella. Was this a reference to the contemporary French poetess of Sapphic leanings Gabrielle Soumet, as Borkowska has suggested? (Borkowska, 2001: 171) Or to Sand's play Gabriel (1839), which like The Heathen, deals with gender instability (I am grateful to Suzan van Dijk for this idea).

In the early 1840s, when she worked as a governess to a series of Polish families in country manors in the Poznan region while maintaining intellectual connections with Warsaw, she was reading, among other things, the historian Jules Michelet, as well as Leroux and Enfantin. Of the works of Michelet, she read Précis de l'histoire moderne (1827), Du prêtre, de la femme et de la famille (1844), Histoire romaine (1835). She speaks only of "books" by Enfantin. As to Leroux, she mentions no specific titles, but Romankówna suggests the following, as there were no others: L'Humanité de son principe et de son avenir ou se trouve exposée la vrai definition de la religion et où on explique le sens, la suite et l'enchaînement du mosaïsme et $d u$ christianisme (1840) and/or Sept discours sur la situation actuelle de la société et de l'esprit humain (1841) (Żmichowska, 1960: 10, 14, 440-441). These works inclined towards a utopian, socialistic understanding of world politics, which was intimately interlinked with a particular interpretation of Christianity. In the case of Leroux, and of his close associate George Sand, politics and religion were perceived as one continuum. In addition, Żmichowska had access (most likely through contacts in Poznan where the censorship was not so strict as in the Russian partition) to the journals Revue des deux Mondes (at this time democratic and progressive, although by the time of the Spring of Nations, it supported the monarchists) and Revue Indépendente, which was edited by Leroux, Sand and Louis Vardot.

The most significant work mentioned in this period, though already read earlier is the novel Corinne, ou de l'Italie by Germaine de Staël (Żmichowska, 1960: 21). I have concluded, on the basis of my research into the occurences of the term "enthusiasm" (French: enthousiasme) in this novel and by Żmichowska - note that standard Polish language dictionaries such as Doroszewski's Stownik jezyka polskiego (1958-1969) date usage to her - that the inspiration for her own use of the term came from Corinne and another work by De Staël: De l'Allemagne (1810). Żmichowska called the group of women with whom she was closely associated in the 1840s, also linked to The Scientific Review, the Enthusiasts. There has been disagreement among scholars as to who precisely these women were: for a long time regarded as female conspirators, the consensus now is that they were geographically 
dispersed but loosed linked by common concerns about female emancipation, social reform, women's education and self-realization (Borkowska 2001; Phillips 2008).

The word "enthusiasm" (entuzjazm), as well as Polish equivalents such as zapat, occurs in the frame of The Heathen, where the very same women named later by Żmichowska as the Enthusiasts also appear, as real-life characters but with pseudonyms, and participate in a Symposium-like discussion with their male counterparts on the meaning of "love": romantic love between sexual partners, the Christian agape or love of one's neighbour, and also the utopian connotations, gleaned most likely from Leroux and Sand, of universal brotherhood and human progress. "Enthusiasm," in this interpretation, would appear to stand for a divinely inspired impulse to goodness affecting political and religious life, collective and individual. This frame debate impacts on the central story - the love of the "apostate" Benjamin for a cosmopolitan femme fatale, punished for his abandonment of the Polish cause - in that it offers interpretations of the novel other than the national-patriotic without actually undermining that one. Meanwhile, it is also possible that Sand's Lélia was one of the inspirations for the novel's eponymous heroine, or anti-heroine, the heathen Aspasja (see my introduction in Żmichowska, 2012).

In the 1930 s, commentators drew attention to the many foreign literary influences on The Heathen. As a result, we can see that the novel was by no means an emanation of Polish exclusivity, but was formed out of the texts that Żmichowska had read, thus making it a truly transnational, intertextual work. Boy-Żeleński edited a new edition with a long introduction, where he draws out influences from Balzac, among others (Żmichowska, 1930). Tadeusz Sinko (1933) discovered references to many late $18^{\text {th }}$-century and early $19^{\text {th }}$-century German neo-Hellenic dramas, as well as to the Tannhäuser legend, recently revived by Wagner's opera (1845) and, perhaps most convincingly, to Théophile Gautier's novel Mademoiselle de Maupin (1835). Apart from Classical elements in those German plays, Żmichowska was also familiar with Greek works: not only does the frame of The Heathen suggest familiarity with Plato's Symposium, she also specifically notes that the character of Alcibiades was inspired by Thucydides's History of the Peloponnesian War (Żmichowska, 2007: 386). Meanwhile Wanda Morzkowska-Tyszkowa (1934) also wrote about French influences, including Corinne, although her interpretation here is different from mine: she does not see De Staël's novel as being connected with "enthusiasm" but rather as an inspiration for Aspasja.

Another significant element in the years immediately leading up to publication of The Heathen was Żmichowska's religious journey. In 1841-1842 she published a triptych of stories with the collective title Excerpts from a Woman's Journey (Wyjatki 
z podrózy kobiety): "Gibraltar," "The Storm" ["Burza”] and "The Ruins of Luxor" ["Zawaliska Luksora"], the first of which appeared in Biblioteka Warszawska (1841) and the others in the journal Pilgrim (Pielgrzym) in 1842. The pieces are highly unorthodox with regard to Catholic doctrine and eventually provoked a conflict with the conservative editor of the latter journal Eleonora Ziemięcka. Elements of pantheism and reincarnation and such notions as blending into a universal world spirit after death reveal the influence of Leroux and possibly other contemporary French thinkers; $\dot{Z}$ michowska herself also identifies a literary influence: John Paul Richter's Titan (1800-1803) (Żmichowska, 2007; 386). This departure from traditional religion was crucial to her later development: she would always seek religious truth outside established religion. In the wake of repression that followed the patriotic uprisings in 1846 (in Austrian Galicia) and 1848 (in Poznań), and the Spring of Nations elsewhere in Europe, Żmichowska was arrested by the tsarist authorities and imprisoned for four years for conspiratorial activities. While in prison, she re-read the Bible and in 1855 converted to the eccentric sect of Andrzej Towiański - ten years after she had probably first heard of it, when prominent Polish émigrés living in Paris, including Mickiewicz, had converted. This episode, however, did not last long - and I suggest that it was linked not only to temporary depression but also to the fact that Towianism was inclusive of women, treating them as spiritual equals; even after her own departure from the sect, Żmichowska continued to defend it as more spiritually energetic than traditional Catholicism. The need for greater inclusiveness in religious expression later attracted her to American non-conformist groups, such as the Quakers and Unitarians, as is evident in her letters of the mid-late 1860s to Izabela Zbiegniewska (Żmichowska, 1967: 66, 99). Such identification also inclined her towards pacifism. While in the 1840 s she had favoured revolutionary movements supporting Polish independence, by the time of the 1863 January Uprising, she was against armed rebellion. Meanwhile, by this time, she was discovering the works of natural scientists (she read several of Charles Darwin's books in English) as well as biblical critics such as Ernest Renan, thus broadening her approach to religious issues from many different perspectives (Phillips, 2008).

It was largely her attitude to Catholicism, and linked to this, feminism in such spheres as promoting women's education and economic emancipation, that Żmichowska acquired the reputation of a "Saint-Simonist" (the criticism of one of her employers and his father in the early 1840s, Wincenty and Adam Turno) and even an "atheist" (bezbożna), although it is clear from correspondence throughout her life that she never abandoned Christian faith as such (Żmichowska, 1960: 411, 
611). She did provoke scandal, however, over certain issues. As a supporter of divorce for women who had been made to marry men they did not love, she defended the divorce of her friend Zofia Węgierska, which it seems had a detrimental effect on plans to make Żmichowska headmistress of a girls' school in Poznań in 1843. One of her most persistent critics was the Capuchin father Honorat (Wacław Florentyn Kośmiński), who attacked her in his sermons as an unbeliever (Phillips, 2008: 319). Even the editor of the women's magazine "Bluszcz" ["Ivy"], Maria Ilnicka, in her obituary of $\dot{Z}$ michowska (1876) preferred to remember her as a literary writer, and carefully avoided mention of her religious beliefs. $\grave{A}$ propos religion, it is interesting to speculate whether this aspect of her identity may have been connected with her sexuality. Since her lifetime, commentators have wondered about her lesbianism: Did awareness of being different - not just as a woman, but a woman who loved other women - provoke a need to seek more inclusive forms of Christian expression beyond that offered by her native culture? Was this, at least in part, the great attraction of the foreign?

The case of Narcyza Żmichowska may seem exceptional in the Polish context, but perhaps it wasn't? Maybe there was more interest in foreign contemporary authors among Polish women living in the former Polish lands - and we only know so much about Żmichowska because of her correspondence and because of The Heathen, in which scholars have identified many, or even mostly non-Polish inspirations. "Western" scholarship on Polish literary history of the first half of the nineteenth century has concentrated on literature in exile, the "great" Romantics, and has examined relatively little of the "home" literature. The career of $\dot{Z}$ michowska and her engagement with the foreign, with the wider European and even North American, is a spur to researching the potential foreign inspirations of other Polish writers active in the home country during the period of the partitions.

\section{Works cited}

A History of Women in the West. IV: Emerging Feminism from Revolution to World War. Eds. Geneviève Fraisse, Michelle Perrot. Cambridge, MA: Belknap Press, Harvard University Press, 1993.

Borkowska, Grażyna. Alienated Women: A Study on Polish Women's Fiction 1845-1918.

Trans. by Ursula Phillips. Budapest: Central European University Press, 2001.

Morzkowska-Tyszkowa, Wanda. Żmichowska wobec romantyzmu francuskiego.

Lwów: Wydawnictwo Zakładu Narodowego im. Ossolińskich, 1934. 
Naszkowska, Klara. The Living Mirror: The Representation of Doubling Identities in the British and Polish Women's Literature. PhD thesis, University of Edinburgh, 2012. https://www.era.lib.ed.ac.uk/bitstream/handle/1842/9821/Naszkowska2012.pdf? sequence $=1$ [accessed: 10.11.2016].

Phillips, Ursula. Narcyza Żmichowska. Feminizm i religia. Warszawa: Instytut Badań Literackich PAN, 2008.

----. "Samodzielny uniwersytet kobiecy. Lektury Narcyzy Żmichowskiej.” Czytanie. Kobieta, biblioteka, lektura. Eds. Agata Zawiszewska, Arleta Galant. Szczecin: Wydawnictwo Naukowe Uniwersytetu Szczecińskiego, 2015. 79-104.

----. "The Upbringing and Education of Women as Represented by Nineteenth-century Polish Women Writers.” Slavonic and East European Review 77.2 (1999): 201-222.

Różewicz, Tadeusz. "Miłość lesbijska w romantycznym przebraniu.” Przygotowanie do wieczoru autorskiego. Ed. Jerzy Tchórzewski. $2^{\text {nd }} \mathrm{ed}$. Warszawa: Państwowy Instytut Wydawniczy, 1977. 128-129.

Sinko, Tadeusz. “Dookoła 'Poganki' Żmichowskiej.” Przegląd Wspótczesny 132-133 (1933): 80-90; 233-239.

Stępień, Marian. Narcyza Żmichowska. Warszawa: Państwowy Instytut Wydawniczy, 1968.

Walczewska, Sławomira. Damy, rycerze i feministki. Kobiecy dyskurs emancypacyjny $w$ Polsce. Kraków: Wydawnictwo eFKa, 1999.

Woźniakiewicz-Dziadosz, Maria. Między buntem i rezygnacją. O powieściach Narcyzy Żmichowskiej. Warszawa: Państwowy Instytut Wydawniczy, 1978.

Żmichowska, Narcyza. Poganka. Introduction by Tadeusz Boy-Żeleński. Kraków: Krakowska Spółka Wydawnicza, 1930.

---. Listy. Vol. I: W kreggu najbliższych. Eds. Stanisław Pigoń, Mieczysława Romankówna. Wrocław: Zakład Narodowy im. Ossolińskich, 1957.

---- Listy. Vol. II: Rozdroża. Eds. Stanisław Pigoń, Mieczysława Romankówna. Wrocław: Zakład Narodowy im. Ossolińskich, 1960.

----. Listy. Vol. III: Miodogórze. Eds. Stanisław Pigoń, Mieczysława Romankówna. Wrocław: Zakład Narodowy im. Ossolińskich, 1967.

----. Listy. Vol. IV: Rozmowy z Julią. Ed. Barbara Winklowa. Warszawa: Instytut Badań Literackich PAN, 2009.

---. Listy. Vol. V: Narcyssa $i$ Wanda. Eds. Barbara Winklowa, Helena Żytkowicz. Warszawa: Instytut Badań Literackich PAN, 2007 [includes Tadeusz Boy-Żeleński's original 1930 introduction].

----. The Heathen. Translated with an introduction by Ursula Phillips. DeKalb, Il.: Northern Illinois University Press, 2012. 
Żmichowska, Narcyza, Baranowska, Julia. Ścieżki przez życie. Wspomnienia. Ed. Mieczysława Romankówna. Introduction by Zofia Kossak. $2^{\text {nd }}$ ed. Wrocław: Ossolineum, 2006.

\title{
With Open Eyes: The Young Narcyza Żmichowska's Reception of Western Cultural Influences
}

\begin{abstract}
Summary
The article discusses the influence of non-Polish authors on the thought and literary works of Narcyza Żmichowska (1819-1876). Using evidence taken from her early diary and prolific lifelong correspondence, it concentrates on the earlier part of her career, regarding this as formative, in particular her visit to France in 1838-1839 and then the period 1840-1846, after she had returned to the Polish lands and was closely involved with the progressive intellectual milieu of "The Scientific Review" ("Przegląd Naukowy"). She was phenomenally well-read and self-educated, especially in French and German authors. The culmination of this period was her best-known novel The Heathen (Poganka, 1846), in which many commentators have observed the influence of foreign literary texts. Her unorthodox approach to religion is also discussed, likewise inspired by reading foreign authors. In conclusion, the question is posed as to whether Żmichowska was as unusual as she appears, or whether more research needs to be done into the foreign reading of other Polish writers of the first half of the $19^{\text {th }}$ century publishing "at home" and not in emigration.
\end{abstract}

Keywords: comparative literature, intertextuality, emancipation, feminism, French 19th-century literature, religious non-conformism

Słowa kluczowe: komparatystyka literacka, intertekstualność, emancypacja, feminizm, dziewiętnastowieczna literatura francuska, nonkonformizm religijny 